Ethiopian Journal of Environmental Studies \& Management 8(4): 408 - 422, 2015.

ISSN:1998-0507

doi: http://dx.doi.org/10.4314/ejesm.v8i4.6

Submitted: February 20, 2015

Accepted: April 28, 2015

\title{
ANALYSIS OF RAINFALL DISTRIBUTION IN OWERRI AND ENUGU, NIGERIA USING PRECIPITATION CONCENTRATION INDEX
}

*ADEGUN, O. AND BALOGUN, I.

Department of Geography, University of Lagos, Akoka-Lagos, Nigeria

\begin{abstract}
The precipitation concentration index (PCI) of Owerri and Enugu for 1974 to 2011 was computed to characterise the rainfall distribution for both locations. The PCl was estimated on an annual and seasonal scale. The seasonal estimation was based on the categorisation of the seasons in eastern Nigeria into long wet season, short wet season, short dry season and dry season. The results of the $\mathrm{PCl}$ computed for Owerri showed that $87 \%$ of the years for which annual $\mathrm{PCl}$ was computed fell within the moderate concentration category range, while for Enugu $71 \%$ of the years fell within the moderate concentration category. For the long wet season for the study period, $74 \%$ and $66 \%$ of the years fell within the uniform precipitation concentration category at Owerri and Enugu, respectively, while $13 \%$ of the years at Owerri, and $16 \%$ of the years at Enugu fell within the moderate precipitation category. The varying degrees of precipitation concentration as indicated by the study implies that effective management of water resources and agriculture, and the control of erosion in the study locations might be more difficult to achieve under the prevailing climatic conditions.
\end{abstract}

Key Words: Precipitation Concentration Index; Owerri, Enugu, Rainfall; Variability

\section{Introduction}

The characteristics and variability of rainfall received within an environment has a strong influence on a number of natural processes such as groundwater recharge and water availability, modification of the fluvial regime, and the likelihood and severity of soil erosion. Furthermore, the spatial and temporal variability of rainfall represent an important component of gaining knowledge of the water balance dynamics on different scales for water resources management and planning (DeLuis et al., 2011; Ezemonye and Emeribe, 2011).
Similarly, information derived through a good understanding of the spatial and temporal characteristics of rainfall is also very important for agricultural planning, flood frequency analysis, hydrological modelling, water resources assessments, assessing and understanding climate change impacts and other environmental assessments (Michaelides et al., 2009 as cited in Ngongondo et al., 2011).

In eastern Nigeria, rainfall is seasonal and varies considerably from year to year. These variations have been held partly responsible for land degradation and loss of biodiversity in the area (Ogbuene, 2010). Within this climatic zone, highest daily

*Corresponding Author: Adegun, O.

Email: badegun@yahoo.com 
rainfalls occur between July and September, with a dry spell or the short dry season interrupting the rains in the month of August. It has however been observed that the August break has not been consistent in recent years (Okonkwo and Mbajiorgu, 2010).

Among the different methodologies of analysing the temporal and spatial distribution of rainfall, Precipitation Concentration Index [PCI], (Oliver, 1980), has been utilised by several authors to characterise rainfall variability. Ngongondo et al., (2011), analysed the rainfall distribution for the period 1960 to 2007 for various locations across Malawi using the PCI. The results of the study indicated that most of the locations had high to very high concentration of rainfall.

Nsubuga et al. (2013), analysed the seasonal and annual distribution of rainfall in 7 seven major drainage sub-basins in Uganda for the period 1940 to 2009. The results of the study indicated that for the seasonal distribution of rainfall, the 2 major sub-basins in the northern part of the country had uniform to moderate seasonal distribution while the other sub-basins had uniform seasonal rainfall. For the annual distribution, all the sub-basins had uniform concentration of rainfall. Similarly, Nsubuga et al. (2014), utilised the PCI to assess the heterogeneity of monthly rainfalls in South-western Uganda for the period 1943 to 1997 . The results of the study showed that the area is characterised by moderate to seasonal rainfall distribution. The study also showed that locations with higher mean rainfall had relatively lower rainfall concentrations, while areas with lower mean rainfall had relatively higher rainfall distribution.

Ndamani and Watanabe (2014), analysed the variability of rainfall in the Lawra District of Ghana for the period 1980 to 2008 using the PCI. The results revealed that seasonal rainfall distribution was moderate, while annual rainfall was irregular.

Kumbuyo et al. (2014), studied the distribution of rainfall in different parts of Malawi for the period 1980 to 2011. The results of the annual PCI for the study locations revealed rainfall distribution patterns that varied from seasonal to moderate and highly seasonal. PCI values computed using mean monthly rainfalls varied between seasonal and highly seasonal.

In recognition of the importance of rainfall and its role in the sustenance of agricultural production, water supply and other socio-economic activities in Eastern Nigeria. This study assesses the concentration and variability of rainfall in Owerri and Enugu between 1974 and 2011 using the Precipitation Concentration Index (Oliver, 1980).

\section{Study Area}

Owerri and Enugu (Figure 1) are located in eastern Nigeria, Latitude $06^{\circ 0} 26^{\prime}$ $54^{\prime \prime}$ and Longitude $07^{\circ} 30^{\prime} 00^{\prime \prime}$ and Latitude $05^{\circ} 29^{\prime} 00^{\prime \prime}$ and Longitude $07^{\circ} 02^{\prime}$ $15^{\prime \prime}$, respectively. The seasonal distribution of rainfall in Eastern Nigeria is controlled by the interaction of the Tropical Continental air mass, the Tropical Maritime air mass and the Equatorial Easterlies. The interaction and arrangements of these three air masses within the region is responsible for the convectional, orographic and frontal rainfall types, which are predominant within the region. The rainfall pattern which is controlled by the movement of the Inter-tropical Convergence Zone (ITCZ) is characterised by a long wet season from April to July, with a short dry season in August, followed by a short wet season from September to October (Momanu, 1975). According to Ofomata (1975a), the short duration, high intensity rains that often occurs at the onset and retreat of the 
rainy season, are of great significance for soil erosion within the east.

Rainfall in Enugu is convectional in nature, and often occurs in quick alternate succession between sunny and dry conditions. The rainfall often occurs as violent downpours, which may be accompanied by thunderstorms, heavy flooding, soil leaching, erosion, gullying and groundwater recharge (Egboka, 1985). In Owerri, the peak rainfall occurs within the months of June, July, September or October, while the months of December to February are characterised by low rainfall.

Five major soil classes are recognised within eastern Nigeria based on morphology, degree of profile development, mineral properties of the underlying rocks, and the slope of the terrain. These are the lithosols, young soils derived from recently deposited materials, ferruginous tropical soils, ferrallitic soils and hydromorphic soils (Ofomata, 1975b). According to Hudec et al. (2006), the textural properties of the surficial soil and the horizontal to gently inclined bedrock of eastern Nigeria make them highly vulnerable to erosion.

\section{Methodology}

Monthly rainfall data for the period 1974-2011 for Owerri and Enugu was obtained from the Nigerian Meteorological Agency (Nimet), Lagos. Statistical descriptions of rainfall characteristics for the two locations were carried out using a number of measures. These include the mean, standard deviation, coefficient of variation, skewness and kurtosis. Skewness and kurtosis were used to test for the normality in the rainfall series, while coefficient of variation was used to identify the extent of rainfall variability and level of reliability. Values between 0 and $15 \%$ were categorised as little variability, while values between 16 and $35 \%$, and greater than $36 \%$ were categorised as moderate and high variability respectively. The rainfall data was also used to analyse the temporal distribution and concentration of rainfall at the study locations based on the Precipitation Concentration Index (PCI).

The PCI was estimated on an annual and seasonal scale, based on the division of the seasons into four categories as shown in Table 1. The number 100 in the formula for the annual PCI (Equation 1) represents 12 months of the year signifying $100 \%$. The numbers 33, 17 and 42 in Equations 2 to 4 represent the number of months in each season as a percentage of 12 months of the year. The PCI for the short dry season (August) was not computed because the square of monthly precipitation and the total monthly precipitation was the same and their division equals one.

According to Oliver (1980), PCI values of less than 10 represent a uniform precipitation distribution or low precipitation concentration, values between 11 and 15 represent a moderate precipitation concentration or moderate precipitation distribution. Values between 16 and 20 represent irregular distribution of rainfall, while values above 20 represent a strong irregularity of precipitation distribution or high precipitation concentration. The Precipitation Concentration Index for the annual, long wet season (LWS), short wet season (SWS) and the dry season (DS) was computed according to equations 1, 2, 3 and 4, respectively. 


$$
\begin{aligned}
& \mathrm{PCI}_{\text {annual }}=\frac{\sum_{\mathrm{i}=1}^{12} \mathrm{P}_{\mathrm{i}}^{2}}{12} \times 100 \\
& \left(\Sigma \mathrm{P}_{\mathrm{i}}\right)^{2} \\
& \Sigma \mathrm{P}_{\mathrm{i}}{ }^{2} \\
& \mathrm{PCI}_{\text {LWS }}=\frac{\mathrm{i}_{\mathrm{i}=1}}{\left(\sum_{\mathrm{i}=1}^{4} \mathrm{P}_{\mathrm{i}}\right)^{2}} \times 33 \\
& \mathrm{PCI}_{\text {SWS }}=\frac{\sum_{\mathrm{i}=1}^{2} \mathrm{P}_{\mathrm{i}}{ }^{2}}{\left.{ }_{\mathrm{i}=1}^{2} \mathrm{P}_{\mathrm{i}}\right)^{2}} \times 17 \\
& \mathrm{PCI}_{\text {DS }}=\frac{\sum_{\mathrm{i}=1}^{5} \mathrm{P}_{\mathrm{i}}^{2}}{\left.\underset{\mathrm{i}=1}{5} \mathrm{P}_{\mathrm{i}}\right)^{2}} \times 42
\end{aligned}
$$

\section{Results and Discussion}

\section{Statistical Characteristics of Rainfall}

The results of the long term rainfall statistics for Owerri and Enugu are presented in Table 2. Long term minimum values of rainfall for annual, long wet season, short dry season, short wet season and dry season for Owerri was $1465.8 \mathrm{~mm}$, $508.9 \mathrm{~mm}, 33 \mathrm{~mm}, 283 \mathrm{~mm}$ and $81.1 \mathrm{~mm}$ respectively. For Enugu, the values were $1220.9 \mathrm{~mm}, 571.5 \mathrm{~mm}, 92.2 \mathrm{~mm}, 307.9 \mathrm{~mm}$ and $3.2 \mathrm{~mm}$ respectively. Maximum rainfall values for annual, long wet season, short dry season, short wet season and dry season was $3005.7 \mathrm{~mm}, \quad 1359.4 \mathrm{~mm}, \quad 641 \mathrm{~mm}$, $955.5 \mathrm{~mm}$ and $499.1 \mathrm{~mm}$ for Owerri while the values for Enugu was $2113.1 \mathrm{~mm}$, $1285.1 \mathrm{~mm}, \quad 462.6 \mathrm{~mm}, \quad 816.1 \mathrm{~mm}$ and $208.3 \mathrm{~mm}$. Average rainfall for annual, long wet season, short dry season, short wet season and dry season for Owerri was $2316.4 \mathrm{~mm}, 947.7 \mathrm{~mm}, 347.7 \mathrm{~mm}, 645.6 \mathrm{~mm}$ and $220.6 \mathrm{~mm}$ respectively while for Enugu the values were $1713.0 \mathrm{~mm}, 882.5 \mathrm{~mm}$, $240.9 \mathrm{~mm}, \quad 517 \mathrm{~mm}$ and $93.6 \mathrm{~mm}$ respectively.

Tests for the assumption of normality of rainfall series based on skewness and kurtosis tests showed that rainfall distribution for most of the seasons does not depart too extremely from normal distribution. The only exception was the distribution of dry season rainfall at Owerri.

At Owerri, the annual rainfall series exhibited a negatively skewed, leptokurtic distribution. A leptokurtic distribution is described as one with positive excess kurtosis, whose shape has a more acute peak around the mean. This signifies a lower probability than a normally distributed variable of values near the mean (Machiwal and Jha, 2012). The long wet season rainfall showed a negatively skewed 
platykurtic distribution. A platykurtic kurtosis has a negative excess kurtosis. Shape-wise, a platykurtic distribution has a lower wider peak around the mean, signifying a lower probability than normally distributed variable of extreme values (Machiwal and Jha, 2012). The short wet season showed a positively skewed platykurtic distribution while the long wet season and the dry season both exhibited a positively skewed leptokurtic distribution.

At Enugu, rainfall distribution for all the seasons does not deviate too extremely from the normal distribution. Rainfall distribution for the annual, long wet season, short dry season and dry season, were all positively skewed and platykurtic, while rainfall for the short wet season exhibited positively skewed, leptokurtic distribution.

Coefficient of variation for the study period at Owerri varied between 14.6\% (long term annual rainfall) and $36.4 \%$ (short wet season). For Enugu, the values ranged between $13.5 \%$ (long term annual rainfall) and $57.2 \%$ (dry season). The values for the long term annual rainfall does not differ too significantly from values obtained in previous studies which showed a value of $12.58 \%$ for Owerri for the period 1981 to 2008 ( Igweze et al., 2014), and 9\% for Enugu for the period 1970 to 2000 (Odekunle et al., 2007). Based on earlier stated categorisation, long term annual rainfall at Owerri and Enugu showed little variability, and by implication higher reliability. According to Olaniran (2002), factors responsible for long term rainfall variability in Nigeria include the Inter-Tropical Discontinuity mechanism, the Tropical Esterly Jet, sea surface temperature anomaly, biogeophysical feedback mechanism, El Nino Southern Oscillation and other teleconnections. Values for the long wet season and short dry season indicated moderate variability, while rainfall occurrence for the dry season showed high level of variability and by implication low reliability.

On a decadal basis, annual rainfall variability at Owerri for the three decades (1980-1989, 1990-1999, 2000-2009) were all within the low variability range of 0 $15 \%$. At Enugu, the situation differs. Annual variability for 1980-1989, and 2000-2009 were within the low variability or high reliability range, while annual rainfall for 1990s exhibited moderate variability. For the long wet season at Owerri, rainfall received between 1980 and 1989, and between 2000 to 2009 showed little variation, while the rains received between 1990 and 1999 showed moderate variability. At Enugu, the same pattern of variability was similarly exhibited for the three decades.

For the short dry season, both locations showed a high level of variability for the three decades. For the dry season at Owerri, a high level of variability was exhibited by the rains received between 1980 and 1989, while moderate variation was shown by the rains received between 1990 and 1999, and between 2000 and 2009. At Enugu, the rains received during the dry season remained highly variable for the three decades.

The short dry season for the three decades at Owerri showed moderate level of variability. At Enugu, moderate level of variability was exhibited in 1980s and 1990s, while low level of variability was shown between 2000 and 2009.

\section{Precipitation Concentration Index}

The results of the PCI for Owerri showed that $87 \%$ of the years for which the annual PCI was estimated fell within the moderate precipitation concentration range, while $13 \%$ fell within the irregular precipitation distribution range. The annual distribution of rainfall plays a pivotal role in the determination of vegetation distribution and the sensitivity of the soils 
in the environment to the process of erosion. Years which experienced irregular distribution of rainfall is a pointer to the fact that a greater proportion of the annual rainfall was received during the months of the rainy season. According to Nsubuga (2013), higher PCI values are an indication that rainfall is more concentrated or confined to a few rainy months during the year. The results of the PCI for the long wet season for the study period also shows that rainfall during the long wet season was mostly uniformly distributed as $74 \%$ of the 38-year data period showed PCI values less than 10 , while $26 \%$ of the period under study exhibited moderate seasonal distribution

For the short wet season, rainfall was generally uniformly distributed, with $87 \%$ of the estimated PCI being within the uniform precipitation distribution category and $13 \%$ being within the moderate precipitation concentration category. For the dry season, rainfall was mostly strongly irregular, with $68.42 \%$ having PCI values above 20 , while $26.3 \%$ and $5.26 \%$ of the period exhibited irregular and moderate distribution of rainfall.

On a decadal basis, the annual PCI for Owerri for 1980-1989, 1990-1999, and 2000-2009 decades mostly fell within the moderate concentration precipitation category, while for the long wet season and the short wet season, rainfall was generally uniformly distributed for all the decades. For the dry season, the PCI for the three decades were mainly in the strongly irregular distribution category. Figures 2 to 5 show the annual, long wet season, short wet season and dry season PCI estimation of Owerri from 1974-2011, while Table 3 presents the decadal summary for the same time period.

For Enugu, the annual PCI values showed that rainfall was predominantly moderately distributed, with $71 \%$ of the annual rainfall for the 38-year period having values ranging between 11 and 15 . Furthermore, $26 \%$ of the annual PCI values denoted irregular distribution of rainfall, while strong irregularity of rainfall distribution occurred in $3 \%$ of the study period.

For the long wet season, $34 \%$ of the rainfall distribution of the study period was within the moderate precipitation concentration category, while $66 \%$ of the rainfall distribution fell within the uniform precipitation distribution category. For the short wet season, $84 \%$ of the study period fell within the uniform rainfall distribution category, while $16 \%$ was within the moderate rainfall distribution category. For the dry season, the rainfall was generally irregular with $95 \%$ of the rainfall distribution exhibiting strong irregularity and 5\% exhibiting irregular distribution.

For the decades spanning 1980-1989, 1990-1999, and 2000-2009, the annual PCI for Enugu was mainly within the moderate precipitation concentration category, while the PCI for the long wet season fell mainly within uniform precipitation distribution category. For the short wet season the uniform precipitation distribution category was predominant, while for the three decades rainfall was strongly irregular. Figures 6 to 9 present the annual, long wet season, short wet season and dry season PCI estimation of Enugu from 1974-2011, while Table 4 presents the decadal summary of the computed PCI for the same time period.

Evidence in this study shows that rainfall at Owerri and Enugu occurs under concentrated conditions. Similar studies in other parts of Africa such as Malawi, (Kumbuyo et al, 2014), Uganda, (Nsubuga, et al ., 2013; Nsubuga et al 2014), and Ghana (Ndamani and Watanabe, 2014) all point to the fact that varying degrees of precipitation concentration and seasonality 
characterise the distribution of rainfall in Africa.

Taking into consideration the conditions of precipitation concentration under which the study locations exists, effective management of water resources, agricultural planning and erosion control can only be achieved by taking cognizance of the relative distribution of rainfall patterns in the area. According to UNESCO (2007), water management, irrigation control, water erosion prevention, and nonirrigated agriculture becomes more difficult under conditions of precipitation concentration.

\section{Conclusion}

Precipitation Concentration Index is an index or descriptor of rainfall variability which in essence means that the index can provide information on water availability within an environment. In South-eastern Nigeria where the water resources are highly dependent on rainfall, an understanding of the spatio-temporal variabilities of rainfall is required to have a better knowledge of the water balance dynamics for water resources planning and management, as well as the mitigation of rainfall related environmental hazards such as flooding and erosion.

\section{References}

De-Luis, M., Gonzales-Hidalgo, J.C., Brunetti, M., and Longares, L.A. (2011). Precipitation concentration changes in Spain 1946-2005. Natural Hazards and Earth Systems Science, 11: 1259-1265. DOI:10.5194/nhess11-1259-2011.

Ezemonye, M.N. and Emeribe, C.N. (2011). Correlogram analysis of trends and cycles in rainfall over southeastern Nigeria. Pakistan Journal of Social Science, 8(6): 325333.

Retrieved

from http://docsdrive.com/pdfs/medwelljou rnals/pjssci/2011/325-333.pdf

Egboka, B. C. E (1985). Water resources problems in the Enugu area of Anambra State, Nigeria. Proceedings of the Jerusalem Symposium, September 1985, IAHS Publications no. 153.

Hudec, P.P., Simpson, F., Akpokodje, E.G, Umenweke, M.O. (2006).

Termination of gully erosion processes, southeastern Nigeria. Proceedings of the Eight Federal Interagency Sedimentation Conference, April, 2-6, 2006. Retrieved from http://pubs.usgs.gov/misc/FISC_1947 -2006/pdf/1st-7thFISCsCD/8thFISC/Session\%209B1_Hudec.pdf

Igweze, A.H., Amagoh, M.N, and Ashinze, A.N. (2014). Analysis of rainfall variations in the Niger Delta region of Nigeria. Journal of Environmental Science, Toxicology and Food Technology, 8(1): 25-30. Retrieved from http://iosrjournals.org/iosrjestft/papers/vol8-issue1/Version6/E08162530.pdf

Kumbuyo, C.P., Yasuda, H., Kitamura, Y., and Shimizu, K. (2014). Fluctuations of rainfall time series in Malawi: An analysis of selected areas. Geofizoka, 13: 13-27.

Machiwal, D., and Jha, M.K. (2012). Hydrologic time series: Theory and practice. Capital Publishing, New Delhi, India, pp 21-25.

Monanu, P.C. (1975). Rainfall. In : Nigeria in maps: Eastern States, Ofomata, G.E.K. (Ed). Ethiope Publishing House, Benin City, Nigeria, pp. 2526.

Ndamani, F. and Watanabe, T. (2014). Rainfall variability and crop production in Northern Ghana: The 
case of Lawra District. Society for Management Systems Internet Journal, 1-8. Retrieved from http://kutar.lib.kochitech.ac.jp/dspace/bitstream/10173/12 61/1/sms13-9480.pdf

Ngongondo, C., Xu, C.Y., Gottschalk, L., and Alemaw, B. (2011). Evaluation of spatial and temporal characteristics of rainfall in Malawi: a case of data scarce region. Theoretical and Applied Climatology, 106: 79-93. Retrieved from http://folk.uio.no/chongyux/papers_S CI/TAC_14.pdf

Nsubuga, F.W.N., Botai, O.J., Olwoch, J.M., deW Rautenbach, C.J, Bevis, Y and Adetunji, A.O. (2013). The nature of rainfall in the main drainage subbasins of Uganda. Hydrological Sciences Journal, 1-33. DOI:10.1080/0262.6667.2013.804188

Nsubuga, F.W.N., Olwoch, J.M., deW Rautenbach, C.J, and Botai, Y. (2014). Analysis of mid-twentieth century rainfall trends and variability over southwestern Uganda. Theoretical and Applied Climatology, 115: 1-19. DOI:10.1007/s00704-0130864-6

Odekunle, T.O., Orinmoogunje, I.O.O., and Ayanlade, A. (2007). Application of GIS to assess rainfall variability impacts of crop yield in Guinean Savanna part of Nigeria. African Journal of Biotechnology, 6(18), 2100-2113. Retrieved from http://www.academicjournals.org/arti cle/article1380374022_Odekunle\%20 et\%20al.pdf

Ofomata, G.E. K. (1975a). Soil Erosion. In: Nigeria in maps: Eastern States, Ofomata, G.E.K. (Ed). Ethiope
Publishing House, Benin City, Nigeria, pp. 41-42.

Ofomata, G.E.K. (1975b). Soil. In : Nigeria in maps: Eastern States, Ofomata, G.E.K. (Ed). Ethiope Publishing House, Benin City, Nigeria, pp. 4345.

Ogbuene, E.B. (2010). Environmental consequences of rainfall variability and deforestation in Southeastern Nigeria. International Journal of Water and Soil Resources Research, 1(1-3): 100-115. Retrieved from http://www.icidr.org/ijwsrr_vollno13_2010/Environmental\%20Conseque nces\%20of\%20Rainfall\%20Variabilit y\%20and\%20Deforestation\%20in\%2 0Southeastern\%20Nigeria.pdf

Okonkwo, G.I. and Mbajiorgu, C.C. (2010). Rainfall-intensity-durationfrequency analyses for Southeastern Nigeria. Agricultural Engineering International: The GIGR Journal, 12: 1-15. Retrieved from http://www.cigrjournal.org/index.php/ Ejounral/article/viewFile/1304/1280

Olaniran, O.J. (2002). Rainfall anomalies in Nigeria: The contemporary understanding. Inaugural Lecture Series, University of Ilorin Retrieved from http://unilorin.edu.ng/inaugurallectures/olaniran.pdf

Oliver, J.E. (1980). Monthly precipitation distribution: A comparative index. Professional Geographer, 32: 300309.

UNESCO (2007). Zonation of water regimes in Latin America and the Caribbean from a climatic point of view, focusing on vulnerable areas. CAZALAC. Documents Technicos del PHI-LAC, N0 8. Retrieved from http://unesdoc.unesco.org/images/002 2/002281/228141S.pdf 


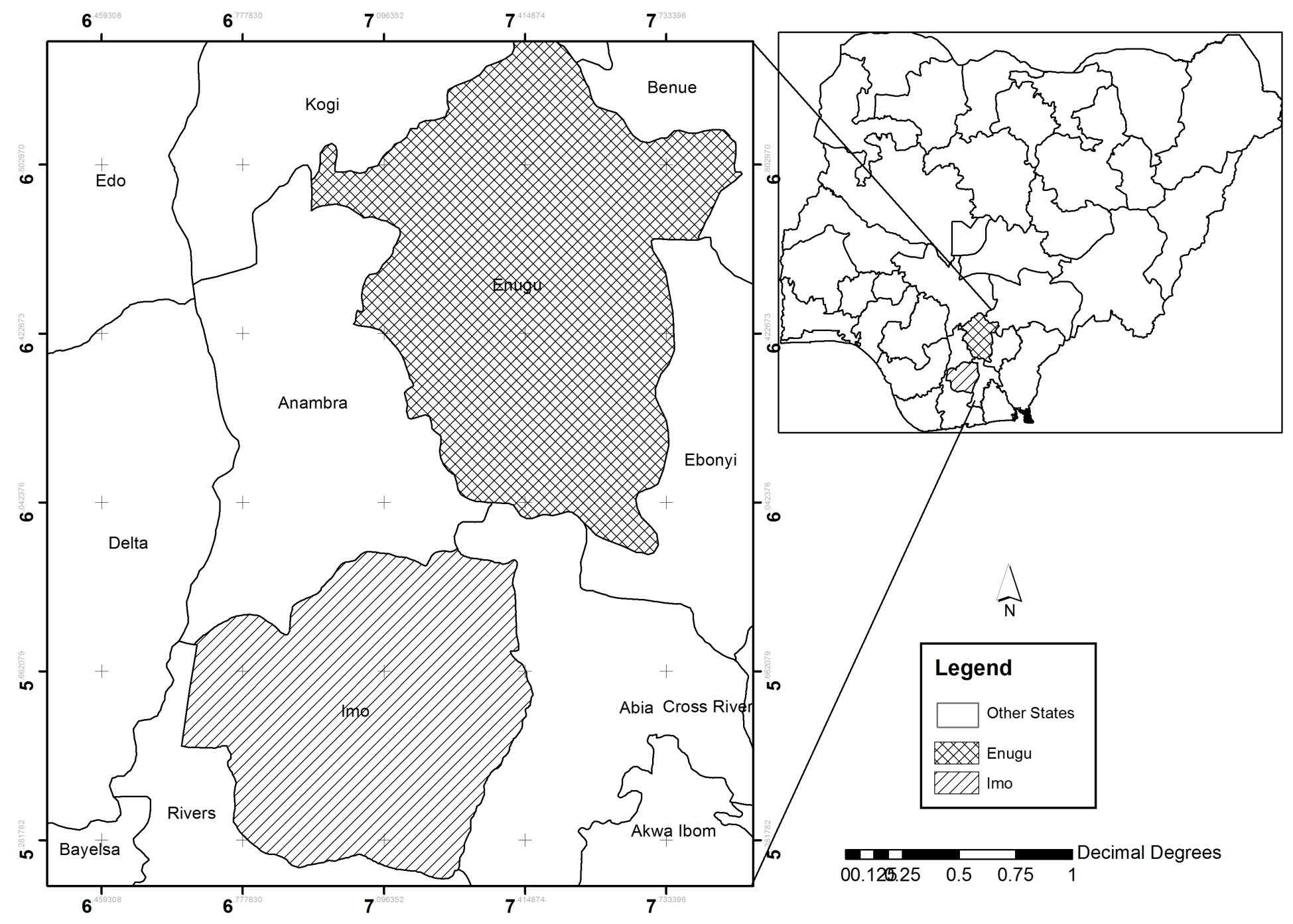

Figure 1: Imo and Enugu States of Eastern Nigeria 


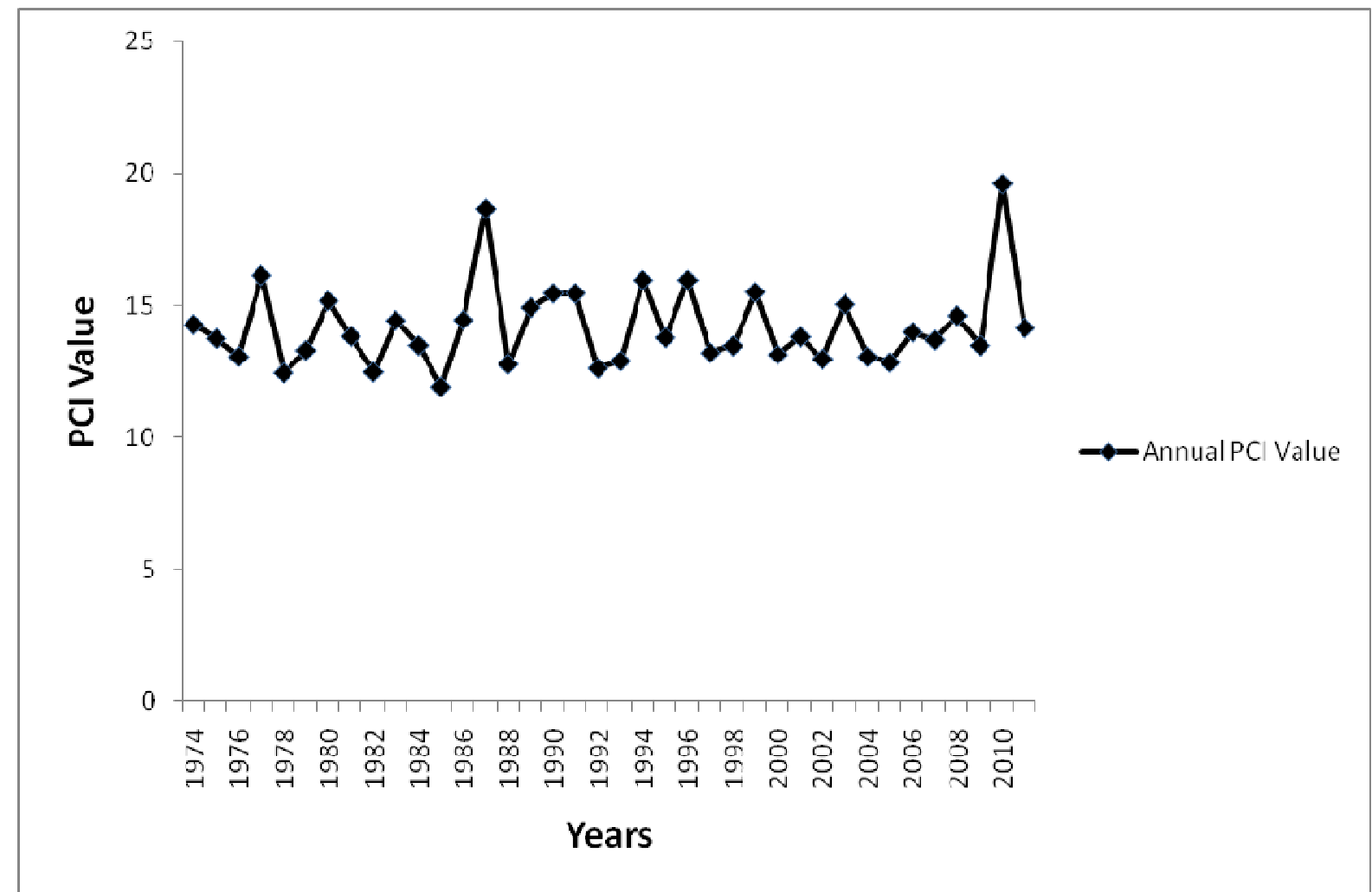

Figure 2: Annual PCI for Owerri at 1974-2011

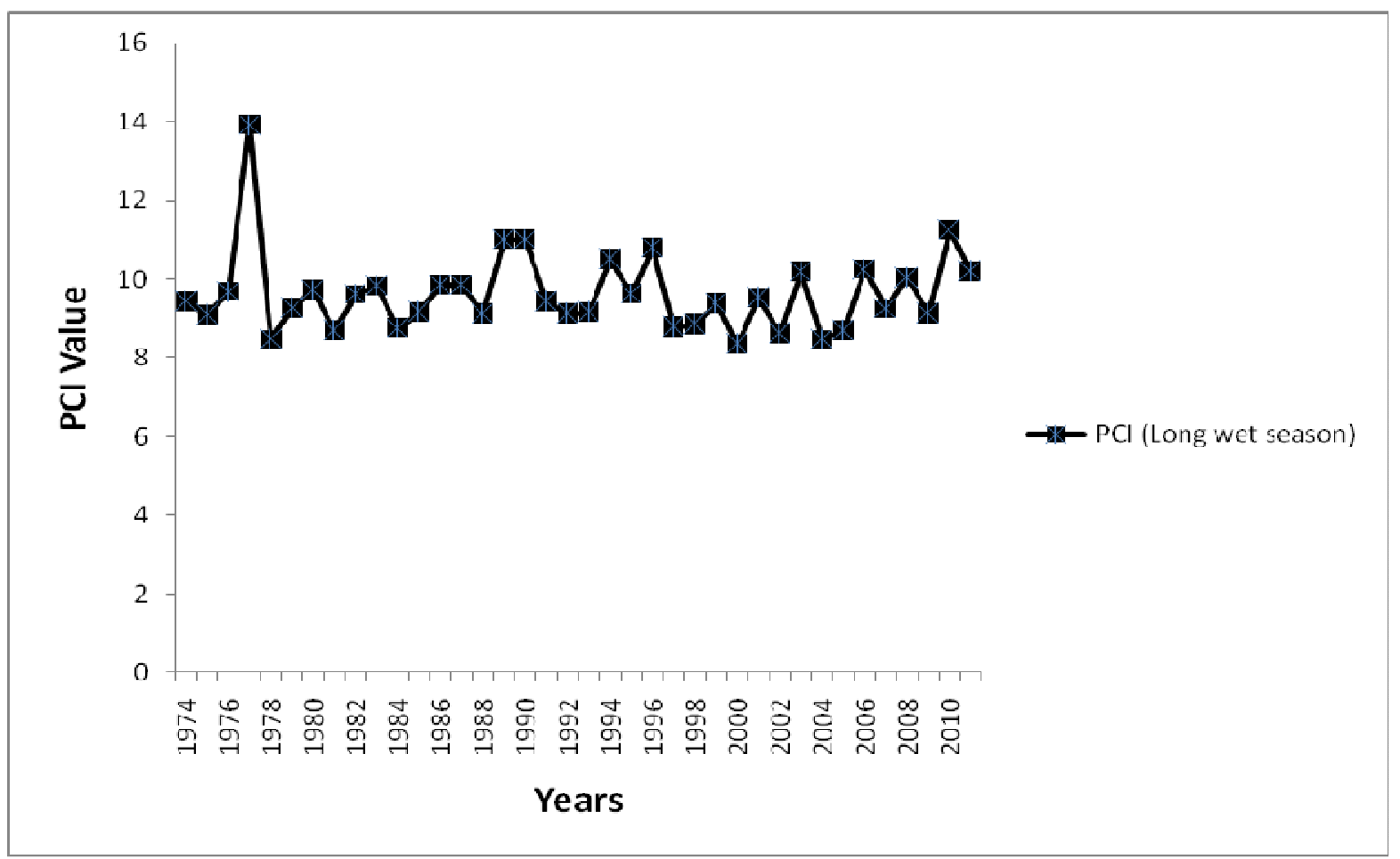

Figure 3: PCI for the Long Wet Season at Owerri (1974-2011) 




Figure 4: PCI for the Short Wet Season at Owerri (1974-2011)



Figure 5: PCI for the Dry Season at Owerri (1974-2011) 


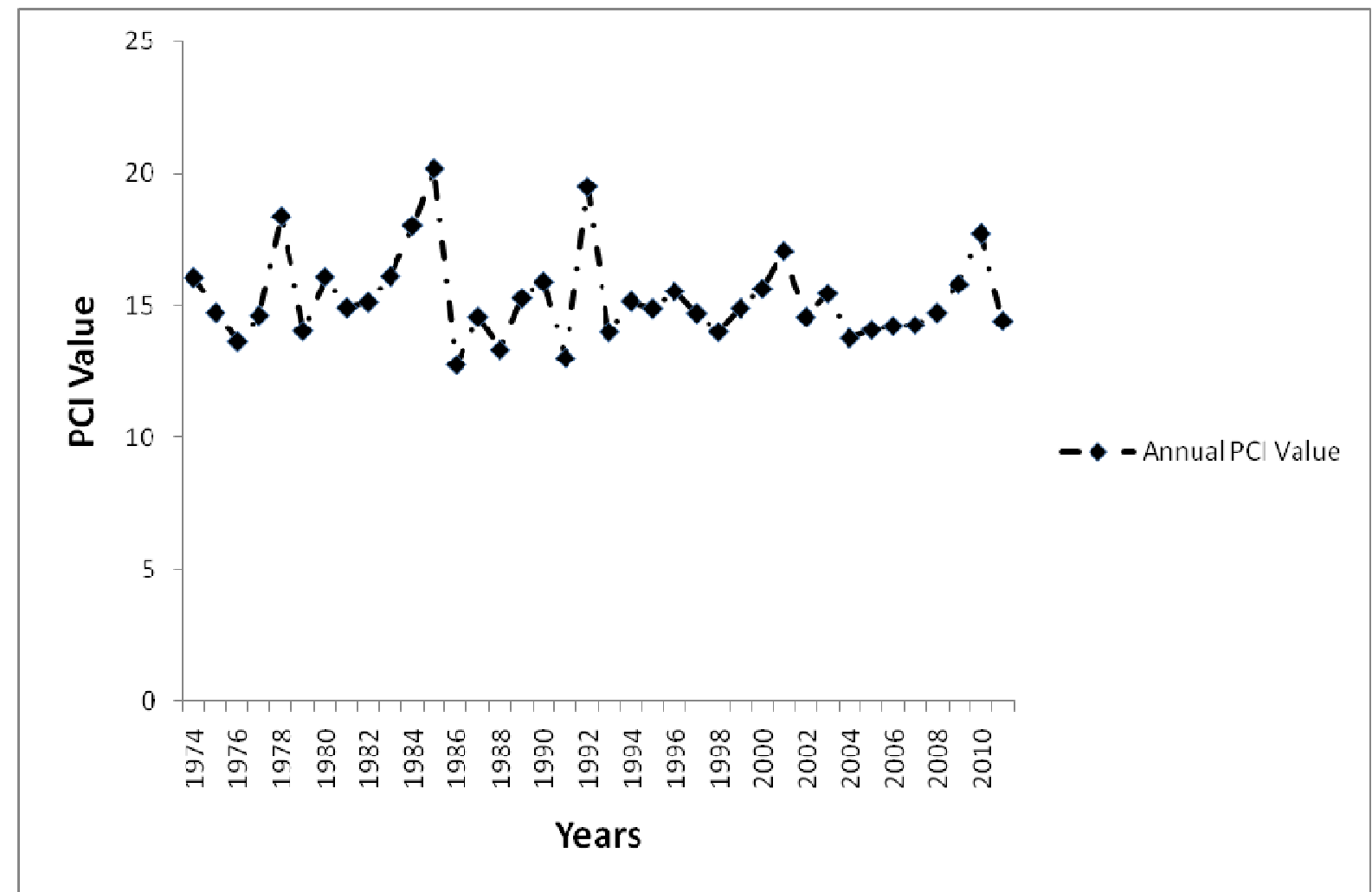

Figure 6: Annual PCI for Enugu at (1974-2011)



Figure 7: PCI for the Long Wet Season at Enugu (1974-2011) 


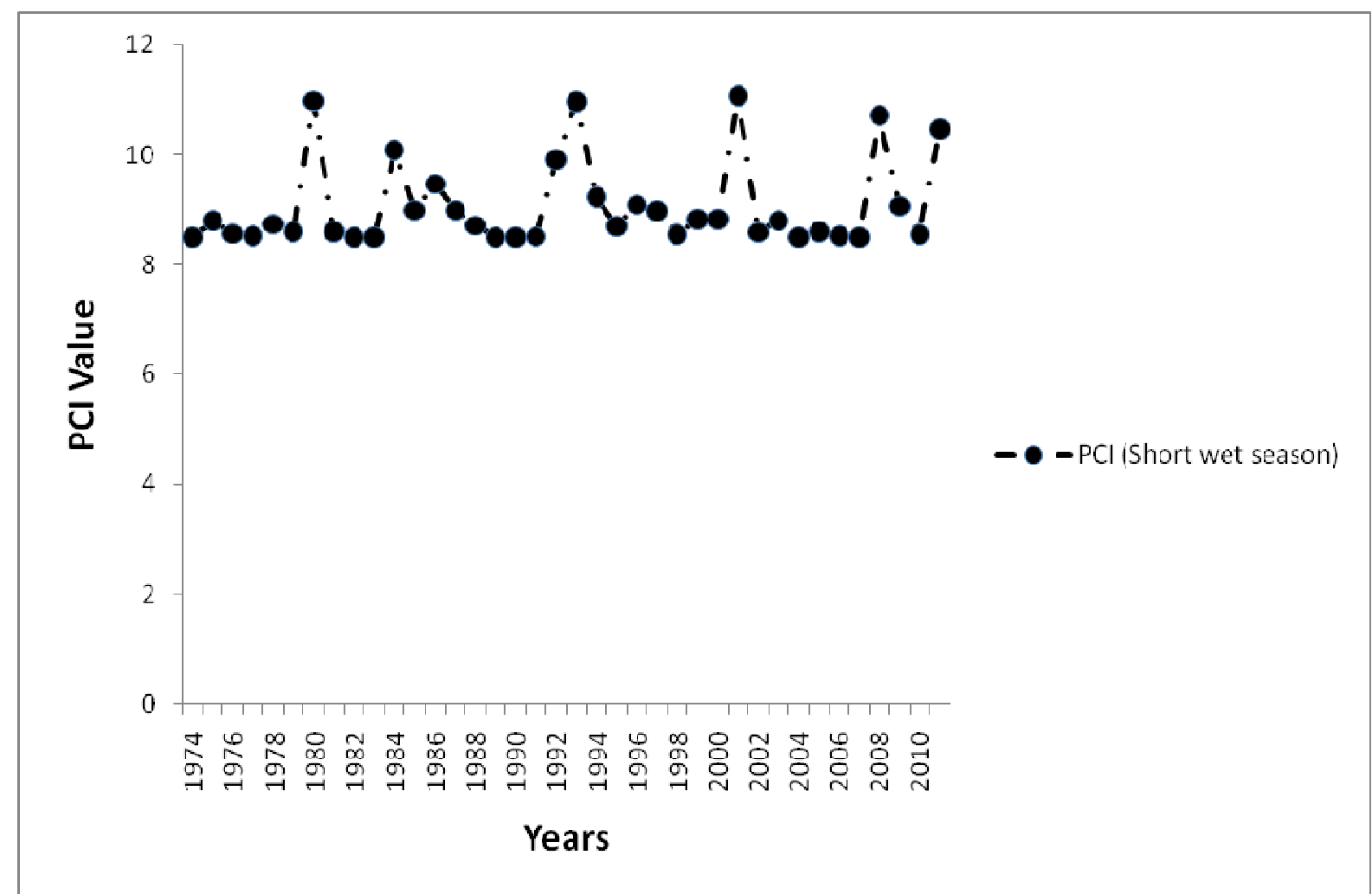

Figure 8: PCI for the Short Wet Season at Enugu (1974-2011)

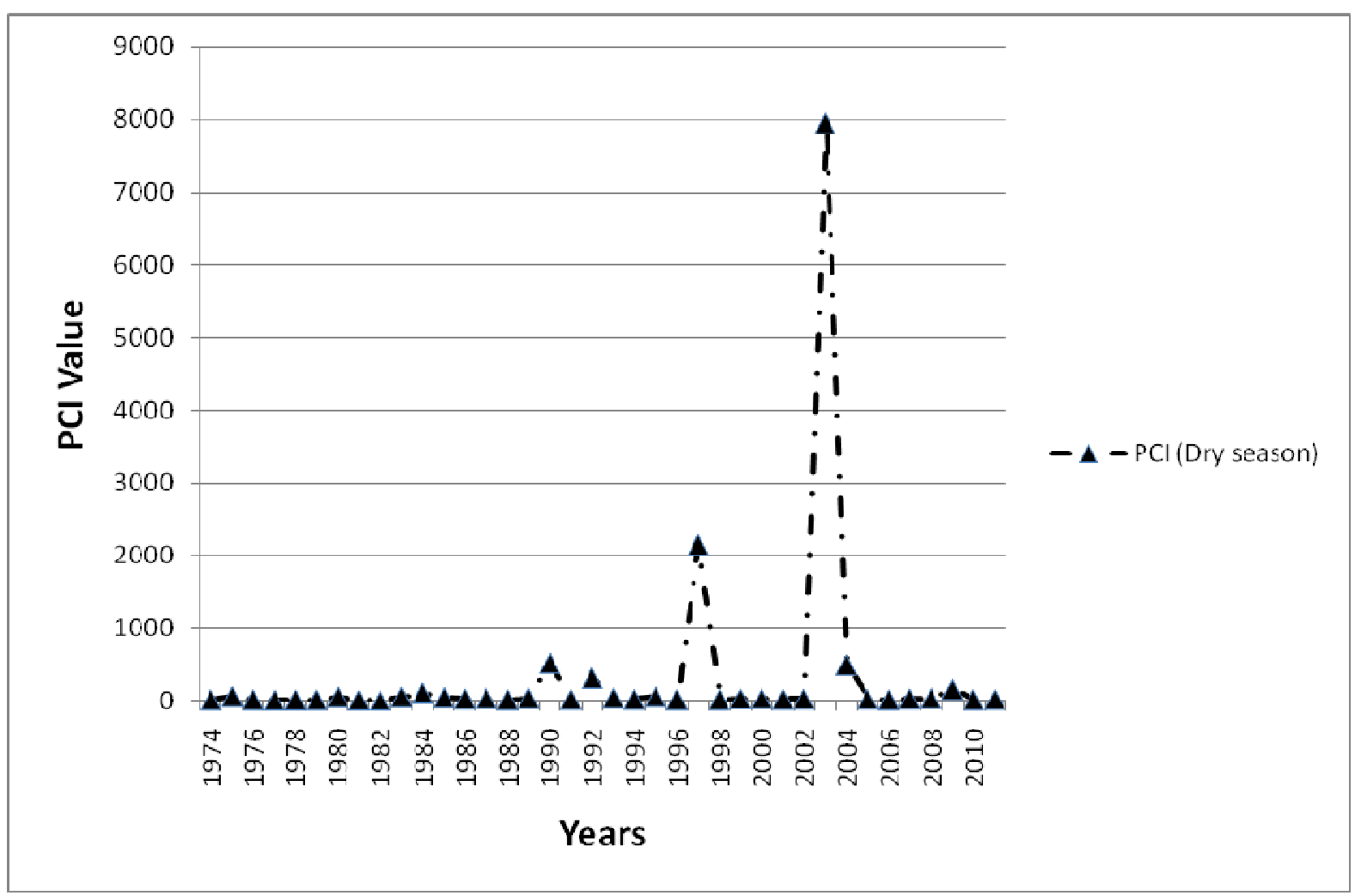

Figure 9: PCI for the Dry Season at Enugu (1974-2011) 
Analysis of Rainfall Distribution in Owerri and Enugu................ADEGUN \& BALOGUN

Table 1: Seasons of the Year and their Percentage as a Function of a Year

\begin{tabular}{ccc}
\hline Season & Months & Number of Months as a \% of 12 Months \\
\hline Long Wet Season & April-July (4 Months) & $33 \%$ \\
Short Dry Season & August (1 Month) & $8 \%$ \\
Short Wet Season & September-October (2 Months) & $17 \%$ \\
Dry Season & November-March (5 Months) & $42 \%$ \\
\hline
\end{tabular}

Table 2: Descriptive Statistics of the of Long Term Rainfall for the Seasons

\begin{tabular}{|c|c|c|c|c|c|}
\hline \multicolumn{6}{|c|}{ Owerri } \\
\hline Statistic & $\begin{array}{l}\text { Long Term } \\
\text { Annual }\end{array}$ & Long Wet Season & $\begin{array}{l}\text { Short Dry } \\
\text { Season }\end{array}$ & $\begin{array}{l}\text { Short Wet } \\
\text { Season }\end{array}$ & Dry Season \\
\hline $\operatorname{Min}(\mathrm{mm})$ & 1465.8 & 508.9 & 33.0 & 283.0 & 81.1 \\
\hline $\operatorname{Max}(\mathrm{mm})$ & 3005.7 & 1359.4 & 641.0 & 955.5 & 499.1 \\
\hline Mean (mm) & 2316.4 & 947.7 & 347.7 & 645.6 & 220.6 \\
\hline Std Deviation & 338.0 & 209.0 & 126.6 & 163.0 & 78.0 \\
\hline Skewness & -0.579 & -0.167 & 0.128 & 0.018 & 1.071 \\
\hline Std Error & 0.383 & 0.383 & 0.383 & 0.383 & 0.383 \\
\hline Kurtosis & 0.250 & -0.614 & 0.180 & -0.416 & 2.980 \\
\hline Std Error & 0.750 & 0.750 & 0.750 & 0.750 & 0.750 \\
\hline $\begin{array}{l}\text { CV (Long } \\
\text { Term) (\%) }\end{array}$ & 14.6 & 22.1 & 36.4 & 25.2 & 35.4 \\
\hline $\begin{array}{l}\text { CV (1980- } \\
1989)(\%)\end{array}$ & 12.3 & 13.5 & 46.7 & 25.2 & 47.0 \\
\hline $\begin{array}{l}\text { CV (1990- } \\
1999)(\%)\end{array}$ & 15.0 & 23.8 & 36.1 & 30.8 & 33.8 \\
\hline $\begin{array}{l}\text { CV (2000- } \\
2009) \\
(\%)\end{array}$ & 12.8 & 21.0 & 38.0 & 20.3 & 29.6 \\
\hline \multicolumn{6}{|c|}{ Enugu } \\
\hline & $\begin{array}{c}\text { Long Term } \\
\text { Annual }\end{array}$ & $\begin{array}{l}\text { Long Wet } \\
\text { Season }\end{array}$ & Short Dry Season & $\begin{array}{c}\text { Short Wet } \\
\text { Season }\end{array}$ & Dry Season \\
\hline $\operatorname{Min}(\mathrm{mm})$ & 1220.9 & 571.5 & 92.2 & 307.9 & 3.2 \\
\hline $\operatorname{Max}(\mathrm{mm})$ & 2113.1 & 1285.1 & 462.6 & 816.1 & 208.3 \\
\hline Mean $(\mathrm{mm})$ & 1713.0 & 822.5 & 240.9 & 517.0 & 93.6 \\
\hline Std Deviation & 231.5 & 170.9 & 103.1 & 119.5 & 53.6 \\
\hline Skewness & 0.123 & 0.581 & 0.357 & 0.453 & 0.568 \\
\hline Std Error & 0.383 & 0.383 & 0.383 & 0.383 & 0.383 \\
\hline Kurtosis & -0.537 & -0.421 & -0.790 & 0.079 & -0.548 \\
\hline Std Error & 0.750 & 0.750 & 0.750 & 0.750 & 0.750 \\
\hline $\begin{array}{l}\text { CV (Long } \\
\text { Term) (\%) }\end{array}$ & 13.5 & 19.4 & 42.8 & 23.1 & 57.2 \\
\hline $\begin{array}{l}\text { CV (1980- } \\
1989)(\%)\end{array}$ & 14.8 & 10.5 & 48.6 & 30.3 & 62.2 \\
\hline $\begin{array}{l}\text { CV (1990- } \\
1999)(\%)\end{array}$ & 16.2 & 18.4 & 47.5 & 21.7 & 46.9 \\
\hline $\begin{array}{l}\text { CV (2000- } \\
2009)(\%)\end{array}$ & 8.6 & 13.3 & 36.6 & 11.7 & 45.4 \\
\hline
\end{tabular}


Table 3: Decadal Summary of PCI for Owerri (1974-2011)

\begin{tabular}{|c|c|c|c|c|}
\hline Decade & Annual PCI & LWS PCI & SWS PCI & DS PCI \\
\hline \multirow{2}{*}{$1980-1989$} & MO - 90\% & $\mathrm{MO}-10 \%$ & $M-10 \%$ & SI- $70 \%$ \\
\hline & IR $-10 \%$ & $U-90 \%$ & $U-90 \%$ & IR $-30 \%$ \\
\hline \multirow{2}{*}{ 1990-1999 } & MO - 80\% & MO- 30\% & $M-10 \%$ & SI $-60 \%$ \\
\hline & IR $-20 \%$ & $\mathrm{U}-70 \%$ & $\mathrm{U}-90 \%$ & $\begin{array}{l}\text { IR }-30 \% \\
\text { MO }-10 \%\end{array}$ \\
\hline \multirow[t]{2}{*}{ 2000-2009 } & MO $-100 \%$ & $\mathrm{MO}-30 \%$ & $\mathrm{MO}-30 \%$ & SI - 70\% \\
\hline & & $\mathrm{U}-70 \%$ & $\mathrm{U}-70 \%$ & $\begin{array}{l}\mathrm{IR}-20 \% \\
\mathrm{M}-10 \%\end{array}$ \\
\hline
\end{tabular}

*MO represents moderate precipitation concentration, $\mathrm{U}$ represents uniform precipitation concentration, IR represents irregular rainfall distribution, SI represents strong irregularity

Table 4: Decadal Summary of PCI for Enugu (1974-2011)

\begin{tabular}{|c|c|c|c|c|}
\hline Decade & Annual PCI & LWS PCI & SWS PCI & DS PCI \\
\hline \multirow[t]{3}{*}{ 1980-1989 } & MO - $60 \%$ & $\mathrm{MO}-40 \%$ & $M-20 \%$ & SI- $100 \%$ \\
\hline & IR $-30 \%$ & $U-60 \%$ & $\mathrm{U}-80 \%$ & \\
\hline & SR $-10 \%$ & & & \\
\hline \multirow[t]{2}{*}{ 1990-1999 } & MO - $80 \%$ & MO- $10 \%$ & $M-10 \%$ & SI - $100 \%$ \\
\hline & IR - $20 \%$ & $\mathrm{U}-90 \%$ & $\mathrm{U}-90 \%$ & \\
\hline \multirow[t]{2}{*}{ 2000-2009 } & MO - $80 \%$ & $\mathrm{MO}-10 \%$ & $\mathrm{MO}-10 \%$ & SR $-100 \%$ \\
\hline & IR $-20 \%$ & $\mathrm{U}-90 \%$ & $\mathrm{U}-90 \%$ & \\
\hline
\end{tabular}

*MO represents moderate precipitation concentration, $\mathrm{U}$ represents uniform precipitation concentration, IR represents irregular rainfall distribution, SI represents strong irregularity 